\author{
Ashiqur Rahman \\ Tomas Bata University in Zlin, \\ Zlin, Crech Republic \\ Email:rahman@fame.utb.cz.
}

\title{
Zoltan Rozsa
}

School of Economics and Management in Public Administration in

Bratislava,

Bratislava, Slovak Republic

Email:zoltan.rozsa@usemvs.sk

\section{Ludmila Kozubikova}

Tomas Bata University in Zlin,

Zlin, Crech Republic

Email:kozubikova@fame.utb.cz.

\section{Martin Cepel}

LIGS University LLC,

Honolulu, Hawaii, USA

Email:cepel@benzinol.com

Abstract. This paper investigates the determinants of loan maturity of small and medium enterprises (SMEs) in the context of Visegrad countries: Czech Republic, Slovak Republic, Poland, and Hungary. The data of instead of for this paper was obtained from the Business Environment and Enterprise Performance Survey (BEEPS), which is a joint project of the European Bank for Reconstruction and Development and the World Bank. By using a binary logistic model, we have found that loan maturity is shorter for older and mature firms, firms owned by female and firms experiencing a shortage of liquidity. At the same time, we have also found that firms having concentrated ownership structure and more tangible assets can borrow for a longer period. In addition to that, we have found evidence that loan maturity is longer for the firms located closer to a bank branch. We also provide empirical support for the assumption that bank low competition is associated with longer maturity. From the obtained results, we may recommend SMEs to borrow from banks that are within their vicinity since this may increase the maturity of loans. Policy makers are recommended to implement policies so 
that to alleviate gender-related discrimination and take initiatives to moderate the level of competition at this market.

Keywords: loan maturity, asymmetric information, female, distance, concentration, collateral, small and medium enterprises.

JEL Classification: G21, G32, L26

\section{INTRODUCTION}

Financing difficulties experienced by small and medium enterprises (SMEs) are an ongoing topic for empirical research in the bank-financing arena (Belás \& Sopková, 2016; Pavelka \& Krchnak, 2015). In comparison to large firms, SMEs are information opaque, and because of that, it is difficult for them to access loans from the external financial market (Spoz, 2014). Due to lack of support from the financial market, SMEs are more dependent on bank lending for their intended projects and staying in business overall.

Empirical research shows that asymmetric information and agency costs in small business lending can be alleviated by imposing a shorter loan maturity because it will reduce the risk-shifting behaviour of the borrower (Berger et al., 2005; Ortiz-Molina \& Penas, 2008; Pietrasieński, \& Ślusarczyk, 2015). Magri (2010) studied the loan maturity structure of Italian SMEs. Heyman et al. (2008) studied privately held Belgian SMEs. Hernandez-Canovas and Koeter-Kant $(2008,2011)$ provided cross-country empirical evidence on the effect of relationship lending and the effect of legal origin of the countries to loan maturity for 19 European countries, respectively. All these studies show that shorter loan maturity can be a handful tool for banks to minimise the agency-related issues in small business lending.

Shorter bank loan maturity is identified as one of the critical issues in entrepreneurial finance, because firms are facing barriers to invest for longer period and hence effecting their business growth (Gavurova et al. 2017). On the other hand, Beck et al. (2006) examining 12 most important financial constraints for SMEs found that lack of long-term credits are the second most important financial obstacles for SMEs. That suggests that shorter loan maturity is an actual problem for SMEs. Regardless of few studies on loan maturity in different European markets, loan maturity structure and its determinants are not yet explored in the context of Visegrad countries. Hence, this gives us the motivation to examine the determinants of loan maturity in the context of Visegrad group.

Authors examining financing difficulties of SMEs concluded that lack of bank financing for SMEs is a general problem of European market overall and the Visegrad countries specifically. Because after the financial crisis banking environment and financing policy of banks changed quite dramatically and that negatively affected the easiness of access to bank finance (Belas and Polach, 2011; Belas et al., 2014; Ključnikov, \& Belás, 2016). Visegrad countries are important in the framework of European economic system and SMEs are their major economic drivers (Sinicakova et al. 2017). Ayyagari et al. (2007) found that SMEs contribute about 65\% of the total employment in Czech Republic, 59\% in Slovak Republic, and 46\% in Hungary and finally yet importantly, about 63\% employment is generated by SMEs in Poland. Moreover, these countries share quite similar economic growth rates, creditor protection rights, legal environments, and hence finding the determinants of loan maturity for SMEs in the Visegrad countries can be helpful for business owners, banks and policy makers while taking the initiatives on creating a financial market suitable for long-term growth of small businesses (Sinicakova \& Gavurova, 2017). 
In this paper, we empirically investigate the role of asymmetric information and the impact of firm riskiness on loan maturity. In addition to that, we examine the role of personal characteristics of a borrower in loan maturity. Because small businesses are mainly owned and managed by entrepreneurs, it is likely that borrower characteristics can have a significant impact on loan maturity (Becerra-Alonso et al., 2016). Furthermore, agency costs in small businesses may also affect loan maturity structure. Since in small businesses, it is hard to separate personal wealth of a borrower from business assets (Ang et al., 1995), the risk-shifting behaviour can be more pronounced for this type of borrowers. Theory related to asymmetric information and collateral suggests that imposing collateral restrictions on bank loans can minimise the adverse selection and moral hazard problem (Boot \& Thakor, 1994), mostly because collateral may signal better borrower quality due to less adverse selection problem (Besanko \& Thakor, 1987). According to this logic of thinking, pledging collateral can increase loan maturity if collateral signals better quality of borrowers.

We further examine the impact of bank-borrower distance in determining loan maturity. Petersen and Rajan (2002) argue that it is hard to monitor the firm located at a far distance from a bank branch. Thus, we claim that bank may try to optimise their monitoring costs by providing short maturity of the loan. However, according to our knowledge, no empirical evidence is yet available to investigate the effect of distance on loan maturity. We also intend to explore the effect of bank market structure of the countries on loan maturity, for example, bank competition and concentration. In a concentrated market, a firm can engage in an exclusive relationship with a bank and this may help risk reduction because of more information transparency (Petersen and Rajan, 1995) thus, also increasing the maturity of loans (Hernandez-Canovas \& Koeter-Kant, 2011; Kaźmierczyk, \& Aptacy, 2016).

The rest of the paper is organised as follows. Section 2 presents theoretical background of our testable variables on loan maturity; Section 3 shows our data set, method, and variables. Section 4 highlights our empirical results, while Section 5 concludes the paper.

\section{THEORETICAL BACKGROUND ON LOAN MATURITY}

The impact of asymmetric information on loan contracts is frequently highlighted in the empirical research that information mismatch creates barriers for banks in lending to their borrowers. SMEs are more affected by the extent of asymmetric information because they cannot show audited financial statements as like as the large corporate firms (Berger \& Udell, 2002). Due to the extent of asymmetric information it is difficult for banks to evaluate the credit quality of SMEs and thus banks may be reluctant to extend loans for a longer period. A few studies examine firm age, firm size and asset tangibility as inverse proxies for information asymmetry in relation to loan maturity and found that reduction of information asymmetry can extend the loan maturity period (Ortiz-Moilna \& Penas, 2008; Magri, 2010; Awartani et al., 2016). Hence, it is more likely that when firms are more transparent it is easier for banks to provide loans for a longer period.

In this paper, we examine borrower gender and experience to capture the effect of borrower personal characteristics on loan maturity. Empirical research finds that in contrast to male borrowers, female borrower face strict credit conditions in the loan market in the form of shorter loan maturity, higher loan price and collateral requirements (Belluchi et al., 2010). Different authors argue that stringent credit restrictions on female based firms may not reflect that female borrowers are riskier than of the male owned firms, but it is due to banks discrimination against female borrowers (Alesina et al., 2013; Belluchi et al., 2010; Carter \& Rosa, 1998). Borrower experience is also relevant in determining the riskiness of the firm. Because an experienced manager can lower the default rates of the firm due to better management of the resources (Hsioa \& Chou, 2015) and as such banks may provide loans for a longer period due to lower 
credit risk. In this regards, Ortiz-Molina \& Penas (2008) find that loan maturity is longer for borrowers who are more experienced and shorter for inexperienced borrowers. Thus, from the prior literature it is evident that borrower personal characteristics can significantly effect loan maturity.

Prior literature quite extensively investigated borrower's probability of default and credit risk in relation loan maturity. Ortiz-Molina \& Penas (2008) examining borrower credit risk and loan maturity find that risky borrowers received loans for short maturity. Similarly, Heyman et al. (2008) find that firms with more credit risk borrow for a shorter period in the Belgian market. Awartani et al. (2016) find that as the default probability of the firm increases, they are more likely to be financed by short-term debt. Magri (2010) find that Italian SMEs those are riskier they receive loans with shorter maturity than the low-risk firms. Hence, the above studies emphasise that borrower credit risk can affect banks decision in determining loan maturity in SME lending.

Agency issues in small business lending has been examined from different perspective including loan maturity. It is argued that small firms facing more agency issues than of the corporate type firms because in small business it is difficult to make a clear distinction between business assets from the owner's personal assets (Ang et al., 1995). Hence, the owner may put his interest in the first place than the interest of the external lenders (Pettit and Singer, 1985). Therefore, to control for agency costs in small business lending, research show that bank can increase monitoring or they can lower the maturity of the loans (Heyman et al., 2008). Myers (1977) argues that agency costs of the loan are higher when the firm has growth opportunities because it may induce underinvestment problem by the owner/manager of the business. Hence, to overcome the underinvestment issue bank can control the suboptimal decision of the borrowers by providing a short-term loan. Magri (2010) posit that firms having an investment in R\&D activities may encounter the underinvestment problem severely than firms that do not invest in innovation or $R \& D$ activities (Androniceanu \& Popescu, 2017). Because it is assumed that innovative firms have more growth opportunities and that may lead to a shorter maturity for innovative firms due to underinvestment problem.

The role of collateral in addressing moral hazard, adverse selection and credit risk management in SME lending is widely recognised in empirical literature (Boot et al., 1991; Boot \& Thakor, 1994; Cipova \& Belas, 2012; Rahman et al., 2016). Theory related to loan maturity and collateral suggests that, pledging collateral can minimise adverse selection problem if the collateral is a signal for better borrower quality. Hence, better borrower quality may lead to a longer maturity of the loan because of risk reduction (Besanko \& Thakor, 1987). Prior literature shows that having collateral in a loan contract in-fact helps to extend loan maturity (Ortiz-Molina \& Penas, 2008; Voordeckers \& Steijvers, 2006). Therefore, collateral can be an important determinant if firms would like to access loans for a longer time.

Bank-borrower distance is identified as an important element in bank financing literature because it can create a spatial differentiation in determining the loan terms while accessing bank credit (Jimenez et al., 2009). The customer transportation costs and bank costs for collecting customer locational information increases with the distances between bank branch and the borrower (Petersen \& Rajan, 2002). Due to higher transportation and monitoring costs banks are reluctant to provide loans to a distant borrower (Hainz et al., 2013). The impact of bank-borrower distance in small business lending is examined from different perspective such as higher collateral requirements (Jimenez et al., 2006; Godlewski \& Weill, 2011), lack of access to finance (DeYoung et al., 2008), higher interest rates on loan (Knyazeva \& Knyazeva, 2012). However, according to our knowledge, the effect of distance on bank loan maturity is yet to be discovered in bank financing literature. It could be the fact that, banks may provide loans to a distant borrower with short-term maturity to optimise the effect of distance on monitoring costs.

Theoretically and empirically the effect of bank market structure (competition and concentration) on loan contract terms are examined in banking literature from different perspectives. Such as collateral 
requirements (Hanedar et al., 2014; Godlewski \& Weill, 2011; Jimenez et al., 2006); interest rates (Bonini et al., 2015; Leon, 2015) and loan maturity (Hernandez-Canovas \& Koeter-Kant, 2011, 2008). Assuming inverse relationship between concentration and competition researcher identify, that lenders provide longterm credit in a concentrated market rather than in a competitive market because in a concentrated market, banks can invest in relationship-based lending that is required to collect soft information from the borrowers and that minimises asymmetric information (Petersen \& Rajan, 2002). Hernandez-Canovas and KoeterKant $(2011,2008)$ examined the effect of bank concentration on loan maturity in 19 European countries and reported that bank concentration is positively related to loan maturity. However, empirical research yet to examine the effect of bank competition and concentration on loan maturity in the Visegrad countries. Thus, current paper will highlight the effect of bank market structure on loan maturity in Visegrad countries for the first time in banking literature.

\section{DATA, METHOD, AND VARIABLES}

\subsection{Data}

The data set we used for our analysis comes from the Business Environment and Enterprise Performance Survey (BEEPS) wave five that is conducted by the European Bank for Reconstruction and Development (EBRD) and the World Bank (WB) during 2012-2014. The data set covers 15,883 enterprises that range from micro, small, medium and large firms in 30 transition countries. We included data from the World Bank indicators (i.e. Doing Business Report) to complement our BEEPS data set for empirical analysis.

The BEEPS data set incorporated 254 firms in the Czech Republic, 268 firms in the Slovak Republic, 542 firms in Poland and 310 firms in Hungary. However, as the aim of this paper is to examine loan maturity structure in the segment of SMEs, therefore, considering the fact we excluded firms that are not in the categories of SMEs. We have defined SMEs according to the conventions of both OECD and BEEPS. SMEs are defined when the number of employees is less than 250. After excluding the large firms and all other missing data, we have obtained 355 firms in four countries that have loan information with maturity.

\subsection{Method and variables}

To examine the determinants of bank loan maturity we created our dependent variable from the BEEPS survey where the firm manager was asked about the duration of their most recent loan or line of credit from the banks in "months". To estimate the logistic regressions, we created a binary depended variable that takes a value of one if the bank loan maturity is more than one year and zero otherwise. Our empirical model to be estimated as follows:

$$
\begin{aligned}
& \text { Maturity (1) = B1 Information Asymmetry + B2 Borrower Characteristics }+ \text { B3 Ex-ante Firm Risk + } \\
& + \text { B4 Agency Costs }+ \text { B5 Collateral }+ \text { B6 Distance }+ \text { B7 Bank Market Structure }+\varepsilon i
\end{aligned}
$$

\subsubsection{Independent variables}

To measure the impact of asymmetric information on loan maturity we analysed four inverse proxies for information asymmetry: firm size (Size), firm age (Age), audited financial reports (Audit) and asset tangibility (Manufacturing). Firm size is a measured through the number of full-time employees the firm employed during the period of BEEPS V survey. It is found that large and older firms are usually exposed 
to less asymmetric information because of more public information is available for large and mature firms (Ortiz-Molina \& Penas, 2008). Similarly, Berger, \& Udell (2002) find that audited financial statement can minimise the extent of asymmetric information because of information disclosure and which can increase the confidence level of the lender. On the other hand, Gompers (1995) finds that asset tangibility reduces the monitoring efforts of the venture capitalists in small business lending and increase the maturity of loans. In this paper, we used manufacturing firm as a proxy for asset tangibility because manufacturing firms have more tangible assets than the service or retail firms. We expect to find a positive relationship between reduction of information asymmetry and loan maturity. Table 1 shows the description of our dependent, independent variables, and source.

To examine the effect of borrower characteristics on loan maturity we have included female borrowers (Female) and borrower experience (Experience) in our model. Female borrowers experience strict credit conditions from the bank in the form of high collateral and higher interest rates because of gender stereotype discrimination (Carter \& Rosa, 1998; Kot et al., 2016). Respecting experience, an experienced owner can manage the business well and thereby reduce the default rates of the firms (Hsiao \& Chou, 2015). Hence, we expect to find a positive relationship between experience and maturity and while a negative relationship with the female borrower.

To examine the impact of firm riskiness on loan maturity, we included three proxies for firm risk: for example, the quality certificate that indicates that if a firm has international quality certificate such as ISO certificate (Quality). Hanedar et al. (2014) find that having an ISO certificate measures the better quality of the firm and hence, low risk. Therefore, we argue that having an ISO certificate may increase the loan maturity because of the better quality of the firm. Then we further included crime as a proxy for firm risk by following Hanedar et al. (2014). Hanedar et al. (2014) examining the same data set as ours find that if the firm is financially affected by any of these activities such as theft, robbery, vandalism or arson are treated as riskier and need to pledge more collateral. Thus, we can expect to find a negative relationship between loan maturity and crime because of firm riskiness. The third proxy for firm risk is the lack of liquidity (Liquidity). Shortage of liquidity can increase the firm default rates due to financial insolvency (Cheng, 2015) and hence we expect to find a negative relationship between a liquidity crisis and loan maturity.

To measure the impact of risk-shifting behaviour and the under-investment problem (agency costs) in our maturity model, we examine ownership structure (Ownership) as a proxy for risk-shifting behaviour and innovation activities (Innovation) as a proxy for underinvestment problem and growth opportunities (Magri, 2010). Ownership is measured by the "percentage of ownership of the firm held by the largest shareholder". Firms with concentrated ownership may have more risk-shifting attitude, and that is why we can expect to find a negative association between ownership concentration and maturity. Innovation is a dummy variable that takes a value of 1 "if the firm has introduced any new products within the last three years and zero otherwise". According to underinvestment theory, we can expect to find a negative relationship between innovation and loan maturity, if innovation is a sign for underinvestment in our sample countries.

To examine the effect of collateral on loan maturity we have a dummy variable that takes a value of 1 if the loan is secured by collateral and otherwise, zero (Ortiz-Molina \& Penas, 2008). If collateral signals better borrower quality in that case having collateral security can longer the maturity of the loan.

We examine the number of bank branches per 100000 adults as inverse proxies for bank-borrower distance because of the fact, that a large number of bank branches can lower the distance between the bank and the borrowing firms due to the geographical distribution of the bank branch. Therefore, the lower distance would make it easier for banks to monitor the firm and it may positively affect loan maturity. Finally, the degree of bank concentration (asset share of the three largest banks in the total banking system) is an inverse measure of bank competition (Hanedar et al., 2014). Hernandez-Canovas and Koeter-Kant 
(2011) stated that banks could better monitor borrower risk when the market is concentrated. Thus, we can expect to find a positive relationship between bank concentration and maturity because of lower borrower risk and better monitoring efforts by the bank.

Table 1

Variable definitions and sources

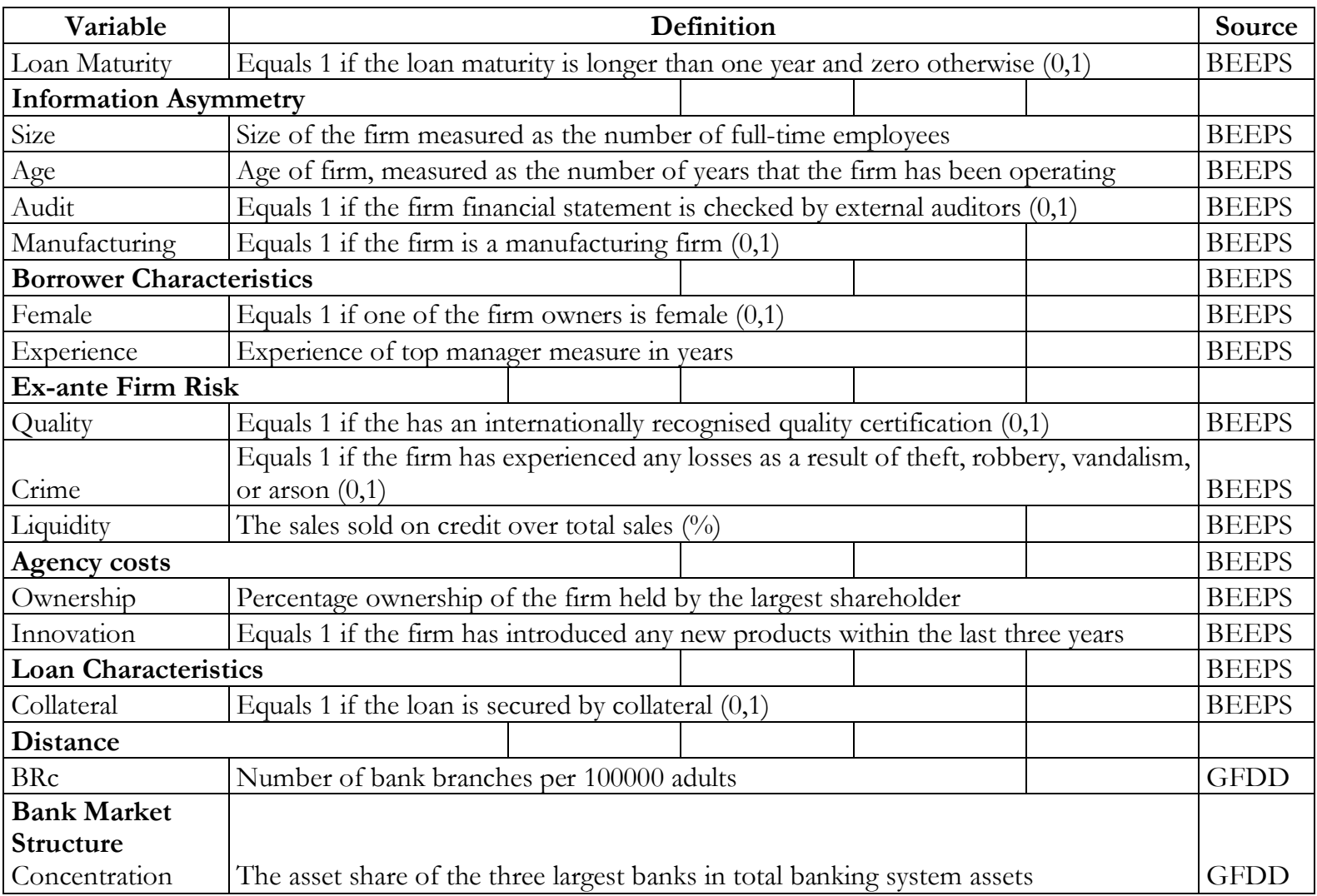

Source: Authors own. This table presents variable definition and sources of the data set. BEEPS = Business Environment and Enterprise Performance Survey. GFDD = Global Financial Development Database.

\section{RESULTS}

\subsection{Descriptive statistics}

In Table 2, we present descriptive statistics for our full sample and cross-country differences in our dependent and independent variables. We can see that about 68 percent of the loans in the Slovak Republic are longer than a year. Whereas, 50 percent of the loans in Hungary are provided for more than one year. It suggests that there are cross-country differences in loan maturity structure in the Visegrad countries.

The table suggests that on an average 45 percent of the firms have audited financial statements and 57 percent of the firms in the Czech Republic have the external audit reports, while only 24 percent of the firms in Poland have it. The survey also suggests that in Hungary, about 54 percent of the SMEs have female ownership and female ownership is lowest in the Czech Republic (about 29 percent). 
Descriptive statistics

\begin{tabular}{|c|c|c|c|c|c|c|c|c|c|c|c|c|c|c|c|}
\hline & Maturit & & & & Manufa & & Experie & & & Liquidi & Owners & Innovati & Collater & & Concent \\
\hline Statist. & $\mathbf{y}$ & Size & Age & Audit & c. & Female & ce & Quality & Crime & $\mathrm{y}$ & ip & on & al & Brc & ration \\
\hline Full Sampl & & & & & & & & & & & & & & & \\
\hline Mean & 59.15 & 38.783 & 18.335 & 0.448 & 0.36 & 0.366 & 20.808 & 0.408 & 0.273 & 54.574 & 76.05 & 0.374 & 0.76 & 24.864 & 74.431 \\
\hline \begin{tabular}{|l} 
Std.D \\
ev
\end{tabular} & 49.22 & 49.03 & 9.08 & 0.497 & 0.48 & 0.482 & 10.082 & 0.492 & 0.446 & 39.913 & 25.419 & 0.484 & 0.427 & 6.015 & 14.79 \\
\hline Min & 0 & 1 & 1 & 0 & 0 & 0 & 2 & 0 & 0 & 0 & 1 & 0 & 0 & 15.35 & 54.74 \\
\hline Max & 1 & 230 & 81 & 1 & 1 & 1 & 55 & 1 & 1 & 100 & 100 & 1 & 1 & 32.53 & 94.67 \\
\hline \begin{tabular}{l|l} 
Obs. \\
\end{tabular} & 355 & 355 & 355 & 355 & 355 & 355 & 355 & 355 & 355 & 355 & 355 & 355 & 355 & 355 & 355 \\
\hline Czech Repu & blic & & & & & & & & & & & & & & \\
\hline \begin{tabular}{l|l} 
& Mean \\
\end{tabular} & 0.5893 & 37.063 & 17.241 & 0.5714 & 0.446 & 0.285 & 22.58 & 0.3839 & 0.4375 & 77.625 & 82.554 & 0.4821 & 0.7589 & 24.25 & 69 \\
\hline \begin{tabular}{|l}
$\begin{array}{l}\text { Std.D } \\
\text { ev }\end{array}$ \\
\end{tabular} & 0.4942 & 44.652 & 5.319 & 0.4971 & 0.499 & 0.453 & 11.097 & 0.488 & 0.498 & 29.924 & 24.152 & 0.501 & 0.429 & & \\
\hline Min & 0 & 4 & 1 & 0 & 0 & 0 & 4 & 0 & 0 & 0 & 20 & 0 & 0 & & \\
\hline Max & 1 & 201 & 25 & 1 & 1 & 1 & 51 & 1 & 1 & 100 & 100 & 1 & 1 & & \\
\hline \begin{tabular}{l|l} 
& Obs. \\
\end{tabular} & 112 & 112 & 112 & 112 & 112 & 112 & 112 & 112 & 112 & 112 & 112 & 112 & 112 & 112 & 112 \\
\hline Slovak Repu & blic & & & & & & & & & & & & & & \\
\hline \begin{tabular}{l|l|} 
& Mean \\
\end{tabular} & 0.6757 & 32.892 & 17.122 & 0.4865 & 0.3108 & 0.3243 & 18.73 & 0.4459 & 0.2027 & 38.649 & 77.216 & 0.2973 & 0.8108 & 26.86 & 94.67 \\
\hline \begin{tabular}{|l|} 
Std.D \\
ev
\end{tabular} & 0.471 & 41.388 & 7.450 & 0.503 & 7.450 & 0.471 & 8.992 & 0.500 & 0.404 & 39.182 & 25.955 & 0.460 & 0.394 & & \\
\hline Min & 0 & 1 & 2 & 0 & 0 & 0 & 2 & 0 & 0 & 0 & 16 & 0 & 0 & & \\
\hline Max & 1 & 211 & 60 & 1 & 1 & 1 & 43 & 1 & 1 & 100 & 100 & 1 & 1 & & \\
\hline \begin{tabular}{l|l} 
& Obs. \\
\end{tabular} & 74 & 74 & 74 & 74 & 74 & 74 & 74 & 74 & 74 & 74 & 74 & 74 & 74 & 74 & 74 \\
\hline Poland & & & & & & & & & & & & & & & \\
\hline \begin{tabular}{l|l} 
Mean \\
\end{tabular} & 0.6067 & 44.169 & 21.348 & 0.2472 & 0.3258 & 0.3483 & 18.865 & 0.2809 & 0.2247 & 48.135 & 72.742 & 0.3933 & 0.6854 & 32.53 & 54.74 \\
\hline \begin{tabular}{|l} 
Std.D \\
ev
\end{tabular} & 0.491 & 56.67 & 13.783 & 0.433 & 0.471 & 0.479 & 8.521 & 0.452 & 0.419 & 38.628 & 26.747 & 0.4912 & 0.467 & & \\
\hline Min & 0 & 2 & 3 & 0 & 0 & 0 & 2 & 0 & 0 & 0 & 12 & 0 & 0 & & \\
\hline Max & 1 & 208 & 81 & 1 & 1 & 1 & 45 & 1 & 1 & 100 & 100 & 1 & 1 & & \\
\hline \begin{tabular}{l|l} 
& Obs. \\
\end{tabular} & 89 & 89 & 89 & 89 & 89 & 89 & 89 & 89 & 89 & 89 & 89 & 89 & 89 & 89 & 89 \\
\hline Hungary & & & & & & & & & & & & & & & \\
\hline \begin{tabular}{l|l} 
& Mean \\
\end{tabular} & 0.5 & 40.65 & 17.638 & 0.4625 & 0.325 & 0.5375 & 22.413 & 0.55 & 0.1625 & 44.2 & 69.55 & 0.275 & 0.8 & 15.35 & 85.22 \\
\hline $\begin{array}{l}\text { Std.D } \\
\text { ev }\end{array}$ & 0.5032 & 52.335 & 7.281 & 0.5017 & 0.4713 & 0.501 & 10.555 & 0.500 & 0.371 & 40.66 & 23.238 & 0.449 & 0.402 & & \\
\hline Min & 0 & 2 & 4 & 0 & 0 & 0 & 3 & 0 & 0 & 0 & 1 & 0 & 0 & & \\
\hline Max & 1 & 230 & 44 & 1 & 1 & 1 & 55 & 1 & 1 & 100 & 100 & 1 & 1 & & \\
\hline Obs. & 80 & 80 & 80 & 80 & 80 & 80 & 80 & 80 & 80 & 80 & 80 & 80 & 80 & 80 & 80 \\
\hline
\end{tabular}

Source: Authors calculation based on BEEPS survey. The table reports descriptive statistics for dependent variable and independent variables for full sample of firms and country level.

With regards to ex-ante firm risk proxies (quality, crime, and liquidity); on an average 41 percent of the SMEs have ISO certificate, and the highest level of quality certificate is available for Hungary (55 percent). The survey suggests that 44 percent of the firms in the Czech Republic had financially affected by theft, robbery, vandalism, and arson and level of crime are lowest in Hungary (16 percent). In our full sample, on an average 55 percent of the total sales are provided on credit and firms in the Czech Republic sold the highest level of products on credit (78 percent).

Proxies for agency costs (ownership and innovation) suggest that firms in our sample are highly concentrated and reluctant to involve in innovation. Specifically, firm ownership is highly concentrated in the Czech Republic (83 percent) whereas; Hungarian firms are least concentrated (70 percent). That means the largest owner in the Czech Republic on an average holds 83 percent of the share in their firms. Considering innovation, only about 38 percent of the firms in our full sample are involved in innovation. Whereas, 28 percent of the firms in Hungary are engaged in innovation.

The survey suggests that on an average 76 percent of the firms obtained loans by providing collateral security. That means that collateral requirements are important loan contract terms in small businesses 
lending and it can have a significant effect on loan maturity. For branch concentration, we see that on an average 25 bank branches are available for 100000 adults. That range from 32 branches in Poland to 15 branches in Hungary. Bank concentration (asset share of the largest three banks) is highest in Slovak Republic (95 percent), and bank market structure is more competitive in Poland (concentration, 55 percent). The results may indicate that bank concentration has a positive effect on loan maturity. As we have seen that firms in the Slovak Republic have the longest loan maturity and high bank concentration in the Slovak Republic might have contributed to this result.

\subsection{Empirical results and discussion}

In Table 3, we present the logistic regressions for loan maturity and in model 1, we analysed the impact of information asymmetry, borrower characteristics, ex-ante firm risk, and agency costs on loan maturity. We separate collateral from this model because loan maturity and loan contract terms such as collateral, interest rate and other fees are determined simultaneously thus, they are considered as endogenous variable (Ortiz-Molina \& Penas, 2008; Jurevičiene \& Skvarciany, 2016). Hence, we examine the effect of collateral in model 2 and model 1 considers all other firm-level variables. Model 3 and model 4 analyses the impact of bank-borrower distance and the effect of bank market structure, respectively.

We hypothesised that reduction of information asymmetry could positively affect the loan maturity and the result suggests that manufacturing firms, which is a proxy for asset tangibility, has a positive effect on loan maturity. Whereas firm size has a negative effect, but we did not find any significant effect of firm age and the audit report on maturity. With asset tangibility and loan maturity, our results are consistent with those of Ortiz-Molina and Penas (2008), Margri (2010), Goyal and Wang (2013) and Awartani et al. (2016). That indicates that tangible assets can minimise asymmetric information and that helps SMEs to obtain loans for a longer period. The main reason would be that tangible assets are easier for lenders to evaluate and it has more information content as stated by Adam and Goyal (2008).

The negative coefficients for firm size contradict with our expectation. It signals that large firms obtain loans for a shorter period than the smaller ones. Our results are consistent with the result of Heyman et al. (2008), Goyal and Wang (2013) and contradicts with the result of Magri (2010), Awertani et al. (2016), OrtizMolina and Penas (2008) and Hernandez-Canovas and Koeter-Kant (2011). There could be a few explanations for this result. At first, short-term loans are cheaper than the long-term loans and large firms may use short-term loans to reduce the costs of loans (Hernandez-Canovas \& Koeter-Kant, 2011). On the other hand, the information content of firm size is difficult to examine because firm size can be used as proxies for different measures; for example, agency costs and asymmetric information (Scherr \& Hulburt, 2001). Hence, firm size may not be an appropriate proxy for capturing the effect of asymmetric information.

On borrower characteristics, we find that female borrowers receive loans for a shorter period in comparison with their male counterparts, but we did not find any effect of borrower experience on maturity. Our results are similar with those of Belluchi et al. (2010), where they also reported shorter loan maturity for female borrowers with respect to the Italian market. It could be the fact that female borrowers might be riskier because survival rate of the female-owned firms is lower than of the male-owned firms according to Boyer and Blazy (2014). Therefore, considering the risk factor for female-owned firms, banks may provide shorter loan maturity to reduce their loan default.

Consistent with our prediction about ex-ante firm risk, we find that firms with higher liquidity risk receive loans for a shorter period. However, we did not find any significant impact of having quality certificate and firms being affected by theft, robbery, vandalism, and arson on loan maturity. The result may highlight the fact the liquidity is a critical factor for firm survival and to maintain a sustainable position in 
the market. Lack of liquidity can increase the chance of default and because of that; banks could be reluctant to offer long-term credit to them. As argued by Awartani et al. (2016) firms having the higher probability of default are less likely to receive long-term debt. The same reasoning could also be applicable for our sample of firms. Because we measure the liquidity crisis on total credit sales. Therefore, a firm selling more products on credits may run out of cash, and that can contribute to default. Thus, this paper provides more evidence that firms with high default risk receive loans for a shorter period.

Contrary to our expectation, we find that concentrated firms receive loans for a longer period. That suggests that ownership concentration is not a sign of risk-shifting behaviour as argued by Pettit and Singer (1985) in the segment of small businesses. Rather the results support for Jensen and Meckling (1976) argument that firms operated my owner-manager have minimal risk of agency costs. It could be the fact that owner-manager is more committed to the business because of personal long-term goal orientation. Hence, banks monitoring inventive is lower in the case of concentrated small businesses that may contribute to a longer maturity. About innovation as the proxy for underinvestment problems, we find negative coefficients for loan maturity, but the results are not statistically significant. Hence, we cannot confirm that firms that are investing in innovation activities are encountering underinvestment problems. Our results are consistent with the findings of Margi (2010), where she did not find any evidence of underinvestment problem for firms that are investing in $\mathrm{R} \& \mathrm{D}$.

We did not find any effect of collateral on loan maturity (model 2). However, we hypothesised that collateral could increase loan maturity because of the signalling effect of better borrower quality. Nevertheless, the insignificant negative coefficients of collateral may indicate that firm that pledges collateral receives loans for a shorter maturity. It could be the fact that pledging collateral is a sign for borrower riskiness and risky borrowers need to provide collateral (Berger et al., 2005; Godlewski \& Weill, 2011). Hence, having collateral on a loan contract may lead to a shorter maturity due to the signalling effect of borrower risk.

According to our expectation, we find that bank branch concentration can increase the duration of loan maturity (model 3). We hypothesised that a large number of branch coverage could lower the distance between the bank and the borrower and that may lead to a longer maturity. It could be that the fact that it is easier for the loan officer to collect soft information from the borrower that is located closer to a bank branch and reduce asymmetric information (Petersen \& Rajan, 2002). Therefore, information transparency could positively affect loan maturity and thanks to the lower distance between the bank and the borrower. On the other hand, a bank can strictly monitor the borrower that is closer to a local bank branch (Heyman et al., 2008) and that may lead to a longer maturity due to lower agency costs. Hence, we propose that closer distance between the bank and the borrower may act as a substitute for bank monitoring through shortterm loans. Contrary to that, the bank could provide short-term loans to a distant borrower to optimise the costs of loan monitoring. Therefore, we argue that as the distance increases it is more likely that borrower would receive a short-term loan and vice versa.

In bank market structure, we find that degree of bank concentration is positively related to loan maturity. Our measures of bank concentration (asset share of the largest three banks in the total banking sector) are significant at 5 percent level. This result is consistent with those of Hernandez-Canovas and Koeter-Kant $(2011$, 2008). It could be the fact that it is easier for banks to monitor the loan when they have more market power and that may lead to a longer loan maturity. Our results also provide support for Petersen and Rajan (2002) notion that lower credit market competition is suitable for banks to invest in building the close relationship and that can reduce information gap. Hence, reduction of asymmetric information may enable the banks to provide loans for a longer period. Another possible reason could be that, in a concentrated market, a borrower has fewer options to move from one to other competitive banks. 
Because of fewer options, the borrower is more likely to stay with his/her main banks for a longer period, and that may facilitate to obtain long-term loans.

Table 3

Logistic regression of loan maturity

\begin{tabular}{|c|c|c|c|c|}
\hline Variable & Model 1 & Model 2 & Model 3 & Model 4 \\
\hline & $\begin{array}{c}\text { Loan Maturity (1/0); } \\
\text { logit }\end{array}$ & $\begin{array}{c}\text { Loan Maturity (1/0); } \\
\text { logit }\end{array}$ & $\begin{array}{c}\text { Loan Maturity (1/0); } \\
\text { logit }\end{array}$ & $\begin{array}{c}\text { Loan Maturity (1/0); } \\
\text { logit }\end{array}$ \\
\hline \multicolumn{5}{|c|}{ Information Asymmetry } \\
\hline Size & $-0.001(0.003)^{*}$ & $-0.023(0.029)^{*}$ & $-0.045(0.018)^{*}$ & $-0.018(0.005)^{*}$ \\
\hline Age & $0.004(0.014)$ & $0.090(0.018)$ & $0.001(0.189)$ & $0.006(0.156)$ \\
\hline Audit & $-0.389(0.249)$ & $-0.261(0.313)$ & $-0.312(0.254)$ & $-0.256(0.268)$ \\
\hline $\begin{array}{l}\text { Manufactur } \\
\text { ing }\end{array}$ & $0.725(0.258)^{* * *}$ & $0.724(0.324)^{* * *}$ & $0.743(0.260)^{* * *}$ & $0.752(0.286)^{* * *}$ \\
\hline \multicolumn{5}{|c|}{ Borrower Characteristics } \\
\hline Female & $-0.159(0.240)^{* *}$ & $-0.158(0.241)^{* *}$ & $-0.080(0.246)^{* *}$ & $-0.0720(0.325)^{* *}$ \\
\hline Experience & $-0.010(0.012)$ & $-0.017(0.023)$ & $-0.026(0.150)$ & $-0.031(0.146)$ \\
\hline \multicolumn{5}{|c|}{ Ex-ante Firm risk } \\
\hline Quality & $0.242(0.247)$ & $0.194(0.319)$ & $0.322(0.248)$ & $0.328(0.280)$ \\
\hline Crime & $-0.047(0.254)$ & $-0.076(0.263)$ & $-0.068(0.256)$ & $-0.062(0.321)$ \\
\hline Liquidity & $-0.008(0.003)^{* * *}$ & $-0.025(0.10)^{* * *}$ & $-0.038(0.004)^{* * *}$ & $-0.046(0.092)^{* * *}$ \\
\hline \multicolumn{5}{|c|}{ Agency Costs } \\
\hline Ownership & $0.005(0.009)^{*}$ & $0.008(0.080)^{*}$ & $0.010(0.025)^{*}$ & $0.026(0.362)^{*}$ \\
\hline Innovation & $-0.255(0.240)$ & $-0.253(0.231)$ & $-0.309(0.243)$ & $-0.018(0.256)$ \\
\hline \multicolumn{5}{|c|}{ Loan Characteristics } \\
\hline Collateral & & $-0.014(0.274)$ & & \\
\hline \multicolumn{5}{|l|}{ Distance } \\
\hline $\mathrm{BRc}$ & & & $0.034(0.020)^{*}$ & \\
\hline \multicolumn{5}{|c|}{ Bank Market Structure } \\
\hline $\begin{array}{l}\text { Concentrati } \\
\text { on }\end{array}$ & & & & $0.023(0.019)^{* *}$ \\
\hline Constant & $0.982(0.525)^{* *}$ & $0.988(0.537) * *$ & $0.094(0.901)^{* *}$ & $1.117(0.8330)$ \\
\hline $\begin{array}{l}\text { Pseudo-R } \\
\text { Square }\end{array}$ & 0.089 & 0.09 & 0.095 & 0.092 \\
\hline $\begin{array}{l}\text { Observatio } \\
\text { ns }\end{array}$ & 355 & 355 & 355 & 355 \\
\hline
\end{tabular}

Source: Authors own estimation.

Statistical significance at the $10 \%, 5 \%, 1 \%$ level is indicated by $*, * *, * * *$ respectively. Standard errors are in parenthesizes.

\section{CONCLUDING REMARKS}

In this paper, we examine the determinants of loan maturity structure in Visegrad countries (Czech Republic, Slovak Republic, Hungary, and Poland) for small and medium enterprises (SMEs). Using a sample of 355 SMEs obtained from the BEEPS survey, we examine the effect of asymmetric information, ex-ante firm risk, borrower specific, collateral, bank-borrower distance, and bank market structure on loan maturity. 
Our expectations about reduced asymmetric information and loan maturity are supported only in the case of asset tangibility while firm size is providing a contradictory result. The information content of firm size is difficult to evaluate as discussed elsewhere hence we have to be careful while examining firm size as an inverse proxy for information asymmetry or better firm quality. Regarding borrower characteristics, it is possible to say that female borrowers do experience strict credit conditions from the lenders and we present empirical evidence with respect on shorter loan maturity. Our findings provide support for ex-ante firm risk and shorter loan maturity. At least firms experiencing a shortage of liquidity is supporting our arguments. Hence, the ex-ante firm risk is a sign for the lenders to decrease the maturity of the loans by which they can reduce their monitoring efforts for the risky borrowers. We did not find any indication that ownership concentration and involvement in innovation activity is a sign for agency costs in our sample. Rather, we find that ownership concentration is a positive signal for the lenders because of lower agency costs. On the other hand, pledging collateral is not an optimal choice for firms if they want to borrow for a longer period. In the context of the current paper, it could be the fact that banks include collateral restrictions on loans to secure their investment so they can recover the loan amount by liquidating the asset and which is not related to loan maturity.

We provide novel evidence that bank-borrower distance can affect loan maturity. Firm located closer to a bank branch can access loans for a longer period, and maturity could be shorter for firms located far away from the branch. We further argue that closer distance can act as alternatives for short-term loan maturity because of monitoring efficiency of the banks. Therefore, SMEs need to carefully think where to apply for a loan if they would like to access it for a longer period. The paper suggests SMEs may consider borrowing from a bank that is within their vicinity to access loans for a longer period. We provide support for the theoretical notion that bank low-competition can increase loan maturity. Hence, the institutional market factor is an important element in determining the maturity structure of the loan. It could be possible that firms in the Slovak Republic and Hungary can access loans for a longer period in compared to the firms in the Czech Republic and Poland because of high bank concentration.

Results of this paper have a few policy implications for the bank supervision authorities and bank managers. First, it is a high time to review the lending policy of the banks that may foster long-term loans for the female borrowers. Female borrowers can contribute to the economy largely if they have easy access to bank finance with less stringent credit terms. Second, banks in Visegrad countries may consider extending their branch coverage to a wider set of customers that can increase their monitoring efficiency. Third, bank concentration can be helpful in getting loans for a longer period, but we should be careful about the other synergic effect of bank concentration. Because concentration gives excessive market power to a particular set of banks and that can adversely affect credit terms (e.g., loan price, collateral requirements, etc.) due to less bargaining power of the customers. Hence, a moderate level of bank competition may reduce the market power of the set of banks, and that can create a balance in the financial market.

\section{ACKNOWLEDGEMENT}

Ashiqur Rahman is thankful to the Internal Grant Agency of FaME TBU No. IGA/FaME/2017/010: Financial Constraints on Economic Activities, for financial support to carry out this research.

\section{REFERENCES}

Adam, T., \& Goyal, V. K. (2008). The investment opportunity set and its proxy variables. Journal of Financial Research, 31(1), 41-63. http://dx.doi.org/10.2139/ssrn.298048 
Alesina, A. F., Lotti, F., \& Mistrulli, P. E. (2013). Do women pay more for credit? Evidence from Italy. Journal of the European Economic Association, 11(suppl_1), 45-66.

Alonso, D. B., Androniceanu, A., \& Georgescu, I. (2016). Sensitivity and vulnerability of European countries in time of crisis based on a new approach to data clustering and curvilinear analysis. Administratie si Management Public, (27), 46-61.

Androniceanu, A., \& Popescu, C. R. (2017). An Inclusive Model for an Effective Development of the Renewable Energies Public Sector. Administratie si Management Public, (28), 81-96.

Ang, J. S., Lin, J. W., \& Tyler, F. (1995). Evidence on the lack of separation between business and personal risks among small businesses. The Journal of Entrepreneurial Finance, 4(2), 197-210.

Awartani, B., Belkhir, M., Boubaker, S., \& Maghyereh, A. (2016). Corporate debt maturity in the MENA region: Does institutional quality matter?. International Review of Financial Analysis, 46, 309-325. http://dx.doi.org/10.1016/j.irfa.2015.10.002

Ayyagari, M., Beck, T., \& Demirguc-Kunt, A. (2007). Small and medium enterprises across the globe. Small business economics, 29(4), 415-434. https://doi.org/10.1007/s11187-006-9002-

Beck, T., Demirgüç-Kunt, A., Laeven, L., \& Maksimovic, V. (2006). The determinants of financing obstacles. Journal of International Money and Finance, 25(6), 932-952. https://doi.org/10.1016/i.jimonfin.2006.07.005

Belás, J., \& Polách, J. (2011). Economic Imbalance and Regulatory Traps in Banking Sector. Finance and the Performance of Firms in Science, Education and Practice 2011. ISBN 978-80-7454-020-2

Belas, J., \& Sopkova, G. (2016). A Model of Entrepreneurial Orientation. Transformation in Business \& Economics, 15(38B), 630-645.

Belás, J., \& Sopková, G. (2016). Significant determinants of the competitive environment for SMEs in the context of financial and credit risks. Journal of International Studies, 9(2), 139-149. doi: 10.14254/2071-8330.2016/9-2/10

Belás, J., Machácek, J., Bartos, P., Hlawiczka, R., \& Hudáková, M. (2014). Business Risks and the Level of Entrepreneurial Optimism among SME in the Czech and Slovak Republic. Journal of competitiveness, 6(2), 30-41.

Bellucci, A., Borisov, A., \& Zazzaro, A. (2010). Does gender matter in bank-firm relationships? Evidence from small business lending. Journal of Banking \& Finance, 34(12), 2968-2984.

Berger, A. N., \& Udell, G. F. (2002). Small business credit availability and relationship lending: The importance of bank organisational structure. The economic journal, 112(477), 32-53. https://doi.org/10.1111/1468-0297.00682

Berger, A. N., ESPINOSA-VEGA, M. A., Frame, W. S., \& Miller, N. H. (2005). Debt maturity, risk, and asymmetric information. The Journal of Finance, 60(6), 2895-2923. https://doi.org/10.5089/9781451862201.001

Besanko, D., \& Thakor, A. (1987). Collateral and rationing: sorting equilibria in monopolistic and competitive credit markets. International Economic Review, 28, pp. 671-689. https://doi.org/10.2307/2526573

Bonini, S., Dell'Acqua, A., Fungo, M., \& Kysucky, V. (2016). Credit market concentration, relationship lending and the cost of debt. International Review of Financial Analysis, 45, 172-179. https://doi.org/10.1016/i.irfa.2016.03.013

Boot, A. W., \& Thakor, A. V. (1994). Moral hazard and secured lending in an infinitely repeated credit market game. International Economic Review, 35, 899-920. https://10.2307/2527003

Boyer, T., \& Blazy, R. (2014). Born to be alive? The survival of innovative and non-innovative French micro-start-ups. Small Business Economics, 42(4), 669-683. https://doi.org/10.1007/s11187-013-9522-8

Cheng, S. (2015). Potential lending discrimination? Insights from small business financing and new venture survival. Journal of Small Business Management, 53(4), 905-923. https://doi.org/10.1111/jsbm.12112

Cipovová, E., \& Belás, J. (2012, November). Impacts of selected methods of credit risk management on bank performance. In Proceedings of the 8th European Conference on Management, Leadership and Governance (Vol. 30, pp. 465473).

DeYoung, R., Glennon, D., \& Nigro, P. (2008). Borrower-lender distance, credit scoring, and loan performance: Evidence from informational-opaque small business borrowers. Journal of Financial Intermediation, 17(1), 113-143.

Gavurova, B., Virglerova, Z., \& Janke, F. (2017). Trust and a Sustainability of the macroeconomic growth Insights from dynamic perspective. Journal of Security and Sustainability Issues, 6(4), 637-648. https://doi.org/10.9770/jssi.2017.6.4(9)

Godlewski, C. J., \& Weill, L. (2011). Does collateral help mitigate adverse selection? A cross-country analysis. Journal of Financial Services Research, 40(1-2), 49-78. https://doi.org/10.1007/s10693-010-0099-y. 
Gompers, P. A. (1995). Optimal investment, monitoring, and the staging of venture capital. The journal of finance, 50(5), 1461-1489. https://doi.org/10.2307/2329323.

Goyal, V. K., \& Wang, W. (2013). Debt maturity and asymmetric information: Evidence from default risk changes. Journal of Financial and Quantitative Analysis, 48(3), 789-817. https://doi.org/10.1017/s0022109013000240.

Hainz, C., Weill, L., \& Godlewski, C. J. (2013). Bank competition and collateral: Theory and evidence. Journal of Financial Services Research, 44(2), 131-148. DOI 10.1007/s10693-012-0141-3.

Hanedar, E. Y., Broccardo, E., \& Bazzana, F. (2014). Collateral requirements of SMEs: The evidence from lessdeveloped countries. Journal of banking \& finance, 38, 106-121. https://doi.org/10.1016/j.jbankfin.2013.09.019

Hernández-Cánovas, G., \& Koëter-Kant, J. (2008). Debt maturity and relationship lending: an analysis of European SMEs. International Small Business Journal, 26(5), 595-617. https://doi.org/10.1177/0266242608094031

Hernández-Cánovas, G., \& Koëter-Kant, J. (2011). SME financing in Europe: Cross-country determinants of bank loan maturity. International Small Business Journal, 29(5), 489-507. https://doi.org/10.1177/0266242611402569

Heyman, D., Deloof, M., \& Ooghe, H. (2008). The financial structure of private held Belgian firms. Small Business Economics, 30(3), 301-313. https://doi.org/10.1007/s11187-006-931-0

Hsiao, Y. J., \& Chou, N. T. (2015). Owner Characteristics and the Cost of Bank Loan: Evidence from Small Business. Retrieved from http://papers.ssrn.com/sol3/papers.cfm?abstract id=2562981

Jensen, M. C., \& Meckling, W. H. (1976). Theory of the firm: Managerial behavior, agency costs and ownership structure. Journal of financial economics, 3(4), 305-360. https:// doi.org/10.1016/0304-405x(76)90026-x

Jimenez, G., Salas, V., \& Saurina, J. (2006). Determinants of collateral. Journal of financial economics, 81(2), $255-281$. https://doi.org/10.1016/j.fineco.2005.06.003

Jiménez, G., Salas, V., \& Saurina, J. (2009). Organizational distance and use of collateral for business loans. Journal of Banking \& Finance, 33(2), 234-243. https://doi.org/10.1016/j.bankfin.2008.07.015

Jurevičienè, D. \& Skvarciany, V. (2016). Camels+t approach for banks' assessment: evidence from the Baltics. Entrepreneurship and Sustainability Issues, 4(2), 159-173. http://dx.doi.org/10.9770/jesi.2016.4.2(4)

Kazmierczyk, J., \& Aptacy, M. (2016). The management by objectives in banks: the Polish case. Entrepreneurship and Sustainability Issues, 4(2), 146-158. http://dx.doi.org/10.9770/jesi.2016.4.2(3)

Ključnikov, A., \& Belás, J. (2016). Approaches of Czech entrepreneurs to debt financing and management of credit risk. Equilibrium. Equilibrium. Quarterly Journal of Economics and Economic Policy, 11(2), 343-365. doi: http://dx.doi.org/10.12775/EQUIL.2016.016.

Ključnikov, A., Kozubíková, L., \& Sopková, G. (2017). The Payment Discipline of Small and Medium-sized Enterprises. Journal of Competitiveness, 8(2), 45-61. DOI: 10.7441/joc.2017.02.04

Kot, S., Meyer, N., \& Broniszewska, A. (2016). A Cross-Country Comparison of the Characteristics of Polish and South African Women Entrepreneurs. Economics \& Sociology, 9(4), 207-221. doi: 10.14254/2071-789X.2016/9$4 / 13$

Leon, F. (2015). Does bank competition alleviate credit constraints in developing countries?. Journal of Banking \& Finance, 57, 130-142. https://doi.org/10.1016/j.bankfin.2015.04.005

Magri, S. (2010). Debt maturity choice of nonpublic Italian firms. Journal of Money, Credit and Banking, 42(2-3), 443-463. https://doi.org/10.1111/j.1538-4616.2009.00294.x

Myers, S. C. (1977). Determinants of corporate borrowing. Journal of financial economics, 5(2), 147-175. https://doi.org/10.1016/0304-405x(77)90015-0

Ortiz-Molina, H., \& Penas, M. F. (2008). Lending to small businesses: The role of loan maturity in addressing information problems. Small Business Economics, 30(4), 361-383. https://doi.org/10.1007/s11187-007-9053-2

Pavelka L., \& Krchnak P. (2015). Competitive advantages of internationally operating companies. Ekonomickomanazerske spektrum, 9(2), 2-6.

Petersen, M. A., \& Rajan, R. G. (1995). The effect of credit market competition on lending relationships. The Quarterly Journal of Economics, 110(2), 407-443. https://doi.org/10.2307/2118445

Petersen, M. A., \& Rajan, R. G. (2002). Does distance still matter? The information revolution in small business lending. The journal of Finance, 57(6), 2533-2570. https://doi.org/10.1111/1540-6261.00505

Pettit, R. R., \& Singer, R. F. (1985). Small business finance: a research agenda. Financial management, 47-60. https://doi.org/10.2307/3665059 
Pietrasieński, P., \& Ślusarczyk, B. (2015). Internationalization of small and medium enterprises: empirical research review on barriers to entry into foreign markets. Polish Journal of Management Studies, 11(1), 113-123.

Rahman, A., Rahman, M. T., \& Kljucnikov, A. (2016). Collateral and SME financing: an analysis across bank size and bank ownership types. Journal of International Studies, 9(2), 112-126.

Sara, C., \& Peter, R. (1998). The financing of male-and female-owned businesses. Entrepreneurship \& Regional Development, 10(3), 225-242. https://doi.org/10.1080/08985629800000013

Scherr, F. C., \& Hulburt, H. M. (2001). The debt maturity structure of small firms. Financial management, 85-111.

Sinicaková, M., \& Gavurová, B. (2017). Single Monetary Policy versus Macroeconomic Fundamentals in Slovakia. Ekonomický časopis (Journal of Economics), 2(65), 158-172.

Sinicakova, M., Sulikova, V., Gavurova, B. (2017). Twin deficits threat in the European union. E \& M Economics and Management, 20(1), 144-156. https://doi.org/10.15240/ tul /001/2017-1-010

Spoz, A. (2014). Significance of the EU Funds in Investments of Small and Medium-Sized Enterprises. Oeconomia Copernicana, 5(4), 61-74. doi: http://dx.doi.org/10. 12775/OeC.2014.027.

Stehell V., Vrbka J. \& Rowland Z. (2016). Using neural networks for determining creditworthiness for the purpose of providing bank loan on the example of construction companies in south region of Czech republic. Ekonomickomanazerske spektrum, 10(2), 62-75.

Thakor, A. V., \& Udell, G. F. (1991). Secured lending and default risk: equilibrium analysis, policy implications and empirical results. The Economic Journal, 101(406), 458-472. https://doi.org/10.2307/2233552

Voordeckers, W., \& Steijvers, T. (2006). Business collateral and personal commitments in SME lending. Journal of Banking \& Finance, 30(11), 3067-3086. https://doi.org/j.bankfin.2006.05.003. 